\title{
Developing Guiding Principles for Teacher Clinical Experience and Induction for Preparing Quality Teacher for the Future.
}

\author{
Mohd Hassan Abdullah, Intan Safinas Mohd Ariff Al-Bakri and Rosnidar Mansor
}

\begin{abstract}
Clinical experience is crucial in developing student teachers' conception about the teaching profession. They are required to make decisions in specific situations and context hence they need to draw on their beliefs, assumptions, knowledge and experience about teaching and learning. This study focuses on developing guiding principles for Teacher Clinical Experience and Induction, which while having the generic characteristics of beginning teacher development. The project will involve doing a critical and comparative analysis of selected models and programmes pertaining to teacher clinical experience and induction. Survey, interviews and focus group discussion were also carried out to collect the relevant data from the ground. Based on the analysis of data, provisional guiding principles were proposed to be considered by any teacher education institution in designing their curriculum framework in order to produce quality teacher for the future.
\end{abstract}

Keywords - Comparative Analysis, Guiding Principles, Clinical Experience, Student Teachers, Teacher Education

\section{INTRODUCTION}

$I^{1}$ $\mathrm{N}$ the 21st century teaching, teachers need to have the right values, skills and knowledge to be effective practitioners who will bring about the desired outcomes of education. Thus, teacher education institution in Malaysia must develop teachers who are able to undertake greater responsibilities as they are at the forefront of educating our children.

It is now universally accepted that the quality of the teaching force determines the quality of education. Hence, teacher education institution plays a vital role to increase the quality of teaching force by improving the current teacher education programme. Due to clinical experience (or more popularly known as teaching practice) is recognized as one of the central component in teacher education programme, therefore, it is important to design a structure for teacher clinical experience which is relevant to and in line with the current practices in school

Mohd Hassan Abdullah is with the Faculty of Music and Performing Arts, Sultan Idris Education University, 35900 Tanjong Malim, Perak, Malaysia (corresponding author's phone (+6)0192127858; e-mail: mohd@fmsp.upsi.edu.my).

Intan Safinas Mohd Ariff Al-Bakri is with the International Affairs Division, Sultan Idris Education University, 35900 Tanjong Malim, Perak, Malaysia (e-mail: safinas@fbk.upsi.edu.my).

Rosnidar Mansor is with the Faculty of Education and Human Development, Sultan Idris Education University, 35900 Tanjong Malim, Perak, Malaysia (e-mail: rosnidar@fppm.upsi.edu.my).

\section{BACKGROUND}

Teachers' clinical experience during the years of pre-service training is perceived as an important factor in producing quality beginning teachers (Ralph, 2007; Darling \& Hammond, 2006, Wilson; 2006) and it is highly valued by student teachers (Farell, 2008; Beck \& Kosnik, 2002). Clinical experience refers to a supervised practical experience or on the job training that provides supported entry to the profession. It is regarded as the cornerstone or the climax of the teacher education program (Barry and King, 2002; Cameron \& Wilson, 1993) whereby student teachers practice and develop their teaching skills. During clinical experience, student teachers are assigned with mentor teachers who will guide the student teachers throughout their experience with the school context. During clinical experience also, observations of classroom teaching will be conducted by mentor teachers and the student teachers' supervisors assigned by the respective institution to foster growth and develop professional wisdom. Student teachers will also be required to reflect on their teaching and write reflective journals.

Clinical experience of the teacher education program is one of the most valuable experiences by both the student teachers. They considered these an introduction to the real context of teaching and learning process and it has a huge implication on their professional development. However, many researchers argue that clinical experience that is not well-constructed and structured may become a fruitless experience to student teachers (Shah Syed Manzar \& Lu, 2013; Darling-Hammond, 2006; Blunden, 2000). One of the arguments is how clinical practice addresses the gap between theory and practice. Blunden (2000) argued that both theory and practice are two different worlds that are not easily aligned. Conelly \& Clandinin (1995) mentioned that theory-practice binary is complex and that theory and beliefs about how theoretical knowledge is applied in practice are diverse and often conflicting. According to Wasim, Khalid, Thomas (2012), the preparation phase of practicum must serve the role of connecting both the theoretical and practical perspectives of the learning and the teaching world.

Darling-Hammond (2006) suggested three critical components of such programs include tight coherence and integration among courses and between course work and clinical work in schools, extensive and intensely supervised clinical work integrated with course work using pedagogies that link theory and practice, and closer, proactive 
relationships with schools that serve diverse learners effectively and develop and model good teaching.

Grootenboer (2006) highlighted that although clinical experience provides the experiences that cannot be replicated in the tertiary classroom, it is viewed as unmediated and unstructured apprenticeship which lacks course work and adequate supervision. Therefore, although clinical experience is recognized for its significance in providing student teachers with the elements that are essential in their professional development, it is criticized for its unstructured nature.

The way clinical experience is organized, supervised, evaluated and integrated into the whole teacher education program also evidently varies across programs and institutions that further influence the diverse impacts on student teachers' professional development.

Hence, this study is pertinent to present Guiding principles for Teacher Clinical Experience and Induction, which while having the generic characteristics of beginning teacher development, is also sensitive to the socio-cultural aspects of Malaysian teachers. It will be constructed based on UPSI's curriculum framework and Teacher Education Model. This model will be generated by taking into considerations the critical elements in forming a clinical experience and induction framework based on empirical findings gained from various sources.

\section{RESEARCH OBJECTIVES}

This study embarks on the following objectives:

i. Conduct a critical, gap and comparative analysis of the available literature and selected teacher clinical experience and teacher induction principles locally and globally in the context of policy and practice.

ii. Benchmark a Clinical Experience and Induction Model for preparing and assisting teachers in their continuous professional development.

iii. Develop Guiding Principles for Malaysian teacher clinical experience and induction.

\section{MEthodology}

Qualitative research methods were utilized in this study. The research design involves a critical review and comparative analysis of selected local (public and private) and international Teacher Clinical Experience and Induction model/framework in the context of policy, theory and practice. It also involves the benchmarking and profiling of knowledge, skills and values of Teacher Clinical Experience and Induction principles that will form the foundation of constructing a curriculum framework for a model of teacher education to develop quality teachers for the future. Based on the analysis, the Teacher Clinical Experience and Induction guiding principles will be proposed.

In this study, benchmarking, gap analysis and preliminary research related to Clinical Experience and Teacher Induction has been conducted.

\section{i. Benchmarking}

Benchmarking was conducted to three local private higher institutions namely HELP University, Taylor's University and SEGi College and four local Public Universities namely University of Science, University of Malaya, University Putra Malaysia and National University of Malaysia. Observation and interview were conducted to obtain required information. Besides, benchmarking was also conducted through document analysis.

\section{ii. Gap Analysis}

Gap analysis was conducted by analyzing documents of teacher education programmes the Clinical Experience and Teacher Induction from Malaysian Higher Education Universities and various renowned world institutions (South Korea, Hong Kong, Australia, United States of America, Canada, United Kingdom, Finland and Singapore) to identify the strength and best practices. Among the renowned world institutions that had been reviewed were College of Education, Seoul National University, South Korea, University of Hong Kong, Queensland University of Technology, Australia, University of Manitoba, Canada, Oregon State University, USA, Michigan State University, University of East Anglia, UK and others.

\section{iii. Preliminary Research}

Preliminary research was done by conducting survey, interview and focus group discussion. The questionnaires consist of two sections, demography and eight sub area related to teaching practice. A total of 36 questions were constructed for these purposes. There were 125 respondents among pre service teachers who have undergone teaching practice and also mentor teachers.

The interview was conducted with eight keys informants to cover three main categories which were effective teaching, effective teachers, clinical experience and induction. Amongst the key informants were excellence teachers, state education officers, principals and COE of private sector.

All the research activities planned for the first phase of this study has been completed. The data has been gathered and analysed. Based on data analysis, five provisional guiding principles have been formulated

\section{V.Proposed GUiding PRINCIPLES FOR THE TEACHER CLINICAL EXPERIENCE AND INDUCTION.}

Based on the document analysis done on local teacher training institutions, it was found that the development of clinical experience and induction programme was not based on explicit guiding principles. Whereas, renown teacher training institutions abroad developed guiding principle prior to clinical experience programme. Furthermore, based on document analysis and area benchmarked, clinical experience consists of 5 major elements which govern the development of teacher clinical experience and induction programme. The elements are the application of subject matter and pedagogical content knowledge in actual school, application of technological pedagogical content knowledge (TPACK) in the 
teaching in actual classroom settings, the use of critical reflection for pedagogic reasoning of the teaching and learning process. The supervision component helps trainee teachers to experience best practices in school. It also exposes trainee teachers to the administrative process or activity of running a school. From these principles, the research team has formulated 5 guiding pringciples for teacher clinical experience and induction. Each of the guiding principles is described in three different perspectives which are value, skill and knowledge. The guiding principles are; (Table 1)

TABLE I

CLINICAL EXPERIENCE AND INDUCTION GUIDING PRINCIPLES WITH THREE PERSPECTIVES OF DESCRIPTORS.

\begin{tabular}{|c|c|c|c|}
\hline \multirow{2}{*}{$\begin{array}{l}\text { Guiding } \\
\text { Principle }\end{array}$} & \multicolumn{3}{|c|}{ Descriptors } \\
\hline & Value & Skills & Knowledge \\
\hline $\begin{array}{l}\text { GUIDING } \\
\text { PRINCIPLE } \\
\text { 1: } \\
\text { Clinical } \\
\text { experience } \\
\text { enables } \\
\text { trainee } \\
\text { teachers to } \\
\text { apply } \\
\text { subject } \\
\text { matter and } \\
\text { pedagogical } \\
\text { content } \\
\text { knowledge } \\
\text { (PCK) in } \\
\text { teaching in } \\
\text { actual }\end{array}$ & $\begin{array}{l}\text { 1. Trainee } \\
\text { teachers are } \\
\text { aware of and } \\
\text { willing to } \\
\text { receive } \\
\text { training on } \\
\text { advance } \\
\text { subject matter } \\
\text { and PCK } \\
\text { application } \\
\text { during } \\
\text { teaching } \\
\text { practice in } \\
\text { actual school } \\
\text { with positive } \\
\text { attitudes and } \\
\text { values. }\end{array}$ & $\begin{array}{l}\text { 1. Trainee } \\
\text { teachers } \\
\text { translate, } \\
\text { interpret and } \\
\text { extrapolate } \\
\text { subject matter } \\
\text { and PCK for } \\
\text { actual school } \\
\text { context during } \\
\text { teaching } \\
\text { practice and } \\
\text { consider the } \\
\text { diverse learners. }\end{array}$ & $\begin{array}{l}\text { 1. Trainee } \\
\text { teachers } \\
\text { understand } \\
\text { the knowledge } \\
\text { of contextual, } \\
\text { professional } \\
\text { and personal } \\
\text { dimensions of } \\
\text { clinical } \\
\text { experience to } \\
\text { apply subject } \\
\text { matter and } \\
\text { PCK in actual } \\
\text { school context } \\
\text { with diverse } \\
\text { learners. }\end{array}$ \\
\hline \multirow[t]{3}{*}{ school. } & $\begin{array}{l}\text { 2. Trainee } \\
\text { teachers } \\
\text { acknowledge } \\
\text { the availability } \\
\text { of multiple } \\
\text { pedagogical } \\
\text { approaches } \\
\text { and strategies } \\
\text { that could be } \\
\text { applied during } \\
\text { teaching } \\
\text { practice. }\end{array}$ & $\begin{array}{l}\text { 2. Trainee } \\
\text { teachers actively } \\
\text { apply subject } \\
\text { matter and PCK } \\
\text { in teaching in } \\
\text { actual school } \\
\text { context with } \\
\text { diverse learners. }\end{array}$ & $\begin{array}{l}\text { 2. Trainee } \\
\text { teachers } \\
\text { understand } \\
\text { the knowledge } \\
\text { of ways and } \\
\text { means of } \\
\text { dealing with } \\
\text { contextual, } \\
\text { professional } \\
\text { and personal } \\
\text { dimensions of } \\
\text { clinical }\end{array}$ \\
\hline & $\begin{array}{l}\text { 3. Trainee } \\
\text { teachers show } \\
\text { preference } \\
\text { and } \\
\text { commitment in } \\
\text { applying } \\
\text { subject matter } \\
\text { and PCK } \\
\text { during } \\
\text { teaching } \\
\text { practice in } \\
\text { actual school } \\
\text { context. }\end{array}$ & $\begin{array}{l}\text { 3. Trainee } \\
\text { teachers } \\
\text { analyze } \\
\text { elements in } \\
\text { relationship with } \\
\text { subject matter } \\
\text { and PCK for } \\
\text { teaching in } \\
\text { actual school } \\
\text { context with } \\
\text { diverse learners. }\end{array}$ & $\begin{array}{l}\text { experience to } \\
\text { apply subject } \\
\text { matter and } \\
\text { PCK in actual } \\
\text { school } \\
\text { context, i.e. } \\
\text { the knowledge } \\
\text { of } \\
\text { conventions, } \\
\text { trends and } \\
\text { sequences, } \\
\text { classifications } \\
\text { and } \\
\text { categories. }\end{array}$ \\
\hline & $\begin{array}{l}\text { 4. Trainee } \\
\text { teachers } \\
\text { conceptualize } \\
\text { the value of } \\
\text { applying } \\
\text { subject matter } \\
\text { and PCK } \\
\text { during } \\
\text { teaching } \\
\text { practice in }\end{array}$ & $\begin{array}{l}\text { 4. Trainee } \\
\text { teachers } \\
\text { analyze } \\
\text { organizational } \\
\text { principles in the } \\
\text { actual school } \\
\text { when applying } \\
\text { subject matter } \\
\text { and PCK during } \\
\text { teaching }\end{array}$ & $\begin{array}{l}\text { 3. Trainee } \\
\text { teachers } \\
\text { understand } \\
\text { the knowledge } \\
\text { of the } \\
\text { universals and } \\
\text { abstractions in } \\
\text { contextual, } \\
\text { professional } \\
\text { and personal }\end{array}$ \\
\hline
\end{tabular}

\begin{tabular}{|c|c|c|c|}
\hline & $\begin{array}{l}\text { actual school } \\
\text { with positive } \\
\text { attitudes and } \\
\text { values. }\end{array}$ & practice. & $\begin{array}{l}\text { dimensions of } \\
\text { clinical } \\
\text { experience to } \\
\text { apply subject } \\
\text { matter and }\end{array}$ \\
\hline & $\begin{array}{l}\text { 5. Trainee } \\
\text { teachers } \\
\text { demonstrate } \\
\text { characteristics } \\
\text { of professional } \\
\text { subject matter } \\
\text { expert and } \\
\text { PCK } \\
\text { practitioners } \\
\text { during } \\
\text { teaching } \\
\text { practice in } \\
\text { actual school } \\
\text { context. }\end{array}$ & $\begin{array}{l}\text { 5. Trainee } \\
\text { teachers plan for } \\
\text { applying subject } \\
\text { matter and PCK } \\
\text { by derivating a } \\
\text { set of abstract } \\
\text { relations } \\
\text { between } \\
\text { pedagogic } \\
\text { principles and } \\
\text { clinical } \\
\text { experience in } \\
\text { actual school } \\
\text { context. }\end{array}$ & $\begin{array}{l}\text { PCK in actual } \\
\text { school, } \\
\text { specifically the } \\
\text { knowledge of } \\
\text { principles and } \\
\text { generalization, } \\
\text { theories, } \\
\text { structures and } \\
\text { learners. }\end{array}$ \\
\hline & $\begin{array}{l}\text { 6. Trainee } \\
\text { teachers } \\
\text { acknowledge } \\
\text { the } \\
\text { importance of } \\
\text { collaboration } \\
\text { and } \\
\text { communicatio } \\
\mathrm{n} \text { in applying } \\
\text { subject matter } \\
\text { and PCK in } \\
\text { actual school } \\
\text { context. }\end{array}$ & $\begin{array}{l}\text { 6. Trainee } \\
\text { teachers actively } \\
\text { apply } \\
\text { communication } \\
\text { skills in teaching } \\
\text { the subject } \\
\text { matter. } \\
\text { 7. Trainee } \\
\text { teachers apply } \\
\text { classroom } \\
\text { management } \\
\text { skills in actual } \\
\text { school context. }\end{array}$ & $\begin{array}{l}\text { 4. Trainee } \\
\text { teachers } \\
\text { comprehend } \\
\text { communicatio } \\
\mathrm{n} \text { skills in } \\
\text { teaching } \\
\text { practice. } \\
5 . \text { Trainee } \\
\text { teachers } \\
\text { comprehend } \\
\text { the knowledge } \\
\text { of classroom } \\
\text { management. }\end{array}$ \\
\hline \multirow{3}{*}{$\begin{array}{l}\text { GUIDING } \\
\text { PRINCIPLE } \\
\mathbf{2} \\
\text { Clinical } \\
\text { experience } \\
\text { enables } \\
\text { trainee } \\
\text { teachers to } \\
\text { apply } \\
\text { technological } \\
\text { pedagogical } \\
\text { content } \\
\text { knowledge } \\
\text { (TPACK) in } \\
\text { teaching in } \\
\text { actual } \\
\text { school } \\
\text { context. }\end{array}$} & $\begin{array}{l}\text { 1. Trainee } \\
\text { teachers } \\
\text { appreciate } \\
\text { training on } \\
\text { TPACK } \\
\text { application } \\
\text { during } \\
\text { teaching } \\
\text { practice in } \\
\text { actual school. }\end{array}$ & $\begin{array}{l}\text { 1. Trainee } \\
\text { teachers } \\
\text { translate, } \\
\text { interpret and } \\
\text { extrapolate } \\
\text { TPACK for } \\
\text { actual school } \\
\text { experience } \\
\text { during teaching } \\
\text { practice. }\end{array}$ & $\begin{array}{l}\text { 1. Trainee } \\
\text { teachers } \\
\text { understand } \\
\text { the knowledge } \\
\text { of contextual, } \\
\text { professional } \\
\text { and personal } \\
\text { dimensions of } \\
\text { clinical } \\
\text { experience to } \\
\text { apply TPACK } \\
\text { in actual } \\
\text { school } \\
\text { context. }\end{array}$ \\
\hline & $\begin{array}{l}\text { 2. Trainee } \\
\text { teachers are } \\
\text { willing to apply } \\
\text { TPACK during } \\
\text { teaching } \\
\text { practice in } \\
\text { actual school. } \\
\text { 3. Trainee } \\
\text { teachers } \\
\text { demonstrate } \\
\text { preference } \\
\text { and } \\
\text { commitment } \\
\text { to applying } \\
\text { TPACK during } \\
\text { real school } \\
\text { experience. }\end{array}$ & $\begin{array}{l}\text { 2. Trainee } \\
\text { teachers actively } \\
\text { apply TPACK in } \\
\text { teaching in } \\
\text { diverse contexts } \\
\text { with diverse } \\
\text { learners. } \\
\text { 3. Trainee } \\
\text { teachers } \\
\text { analyze } \\
\text { elements in and } \\
\text { relationship } \\
\text { among TPACK } \\
\text { for teaching in } \\
\text { real contexts. }\end{array}$ & $\begin{array}{l}\text { 2. Trainee } \\
\text { teachers } \\
\text { understand } \\
\text { the knowledge } \\
\text { of ways and } \\
\text { means of } \\
\text { dealing with } \\
\text { contextual, } \\
\text { professional } \\
\text { and personal } \\
\text { dimensions of } \\
\text { clinical } \\
\text { experience to } \\
\text { apply TPACK } \\
\text { in actual } \\
\text { school. }\end{array}$ \\
\hline & $\begin{array}{l}\text { 4. Trainee } \\
\text { teachers } \\
\text { conceptualise } \\
\text { the value of } \\
\text { applying } \\
\text { TPACK during } \\
\text { teaching } \\
\text { practice. }\end{array}$ & $\begin{array}{l}\text { 4. Trainee } \\
\text { teachers } \\
\text { analyze } \\
\text { organisational } \\
\text { principles in } \\
\text { actual school } \\
\text { context when } \\
\text { applying TPACK } \\
\text { during teaching }\end{array}$ & $\begin{array}{l}\text { 3. Trainee } \\
\text { teachers } \\
\text { understand } \\
\text { the knowledge } \\
\text { of the } \\
\text { universals and } \\
\text { abstractions in } \\
\text { contextual, } \\
\text { professional }\end{array}$ \\
\hline
\end{tabular}




\begin{tabular}{|c|c|c|c|}
\hline & $\begin{array}{l}\text { 5. Trainee } \\
\text { teachers } \\
\text { demonstrate } \\
\text { characteristics } \\
\text { of professional } \\
\text { TPACK } \\
\text { practitioners } \\
\text { during } \\
\text { teaching } \\
\text { practice. }\end{array}$ & $\begin{array}{l}\text { 5. Trainee } \\
\text { teachers plan for } \\
\text { applying TPACK } \\
\text { through a set of } \\
\text { abstract } \\
\text { relations } \\
\text { between } \\
\text { pedagogic } \\
\text { principles and } \\
\text { clinical } \\
\text { experience in } \\
\text { real school } \\
\text { context. } \\
6 \text {. Trainee } \\
\text { teachers apply } \\
\text { creativity and } \\
\text { innovation } \\
\text { through TPACK } \\
\text { in teaching } \\
\text { practice. } \\
7 . \text { Trainee } \\
\text { teachers apply } \\
\text { creativity and } \\
\text { innovation in } \\
\text { preparing } \\
\text { teaching } \\
\text { resources. }\end{array}$ & $\begin{array}{l}\text { and personal } \\
\text { dimensions of } \\
\text { clinical } \\
\text { experience to } \\
\text { apply TPACK } \\
\text { in actual } \\
\text { school } \\
\text { experience, } \\
\text { specifically the } \\
\text { knowledge of } \\
\text { principles and } \\
\text { generalisation, } \\
\text { theories and } \\
\text { structure. }\end{array}$ \\
\hline $\begin{array}{l}\text { GUIDING } \\
\text { PRINCIPLE } \\
\mathbf{3} \\
\text { Clinical } \\
\text { experience } \\
\text { affords } \\
\text { critical } \\
\text { reflection for } \\
\text { pedagogic } \\
\text { reasoning of } \\
\text { the teaching } \\
\text { and learning } \\
\text { process as } \\
\text { well as } \\
\text { professional } \\
\text { and } \\
\text { personal } \\
\text { experience } \\
\text { as a trainee } \\
\text { teacher. }\end{array}$ & $\begin{array}{l}\text { 2. Trainee } \\
\text { teachers } \\
\text { acknowledge } \\
\text { the } \\
\text { significance of } \\
\text { reflecting } \\
\text { critically on } \\
\text { their } \\
\text { classroom } \\
\text { decisions and } \\
\text { relate them to } \\
\text { their } \\
\text { theoretical } \\
\text { knowledge } \\
\text { about teaching } \\
\text { and learning } \\
\text { received in } \\
\text { their teacher } \\
\text { training } \\
\text { course. }\end{array}$ & $\begin{array}{l}\text { 1. Trainee } \\
\text { teachers } \\
\text { translate, } \\
\text { interpret and } \\
\text { extrapolate } \\
\text { critical reflection } \\
\text { in the teaching } \\
\text { and learning } \\
\text { process for } \\
\text { professional and } \\
\text { personal } \\
\text { development } \\
\text { during teaching } \\
\text { practice. }\end{array}$ & $\begin{array}{l}\text { 1. Trainee } \\
\text { teachers } \\
\text { understand } \\
\text { the range of } \\
\text { concepts and } \\
\text { skills } \\
\text { associated } \\
\text { with } \\
\text { declarative \& } \\
\text { procedural } \\
\text { knowledge } \\
\text { and how they } \\
\text { are applied in } \\
\text { practice } \\
\text { through critical } \\
\text { reflection of } \\
\text { the teaching } \\
\text { and learning } \\
\text { process. } \\
2 . \text { Trainee } \\
\text { teachers } \\
\text { understand } \\
\text { that critical } \\
\text { reflection } \\
\text { during field } \\
\text { experiences } \\
\text { contribute to } \\
\text { equipping } \\
\text { them with the } \\
\text { knowledge } \\
\text { and skills to } \\
\text { solve } \\
\text { problems and } \\
\text { make } \\
\text { pedagogical } \\
\text { decisions } \\
\text { which serve } \\
\text { diverse } \\
\text { learners well } \\
\text { and to learn } \\
\text { continuously }\end{array}$ \\
\hline
\end{tabular}

\begin{tabular}{|c|c|c|c|}
\hline & & & $\begin{array}{l}\text { from their } \\
\text { practice. }\end{array}$ \\
\hline & $\begin{array}{l}\text { 3. Trainee } \\
\text { teachers } \\
\text { conceptualize } \\
\text { the value of } \\
\text { critical } \\
\text { reflection in } \\
\text { the teaching } \\
\text { and learning } \\
\text { process for } \\
\text { professional } \\
\text { and personal } \\
\text { development } \\
\text { during } \\
\text { teaching } \\
\text { practice. }\end{array}$ & & $\begin{array}{l}\text { 3. Trainee } \\
\text { teachers } \\
\text { understand } \\
\text { the knowledge } \\
\text { of ways and } \\
\text { means of } \\
\text { dealing with } \\
\text { critical } \\
\text { reflection for } \\
\text { pedagogical } \\
\text { reasoning and } \\
\text { of the teaching } \\
\text { and learning } \\
\text { process as } \\
\text { well as } \\
\text { professional } \\
\text { and personal } \\
\text { experience } \\
\text { during } \\
\text { teaching } \\
\text { practice, i.e. } \\
\text { evaluating } \\
\text { lessons, } \\
\text { analyzing } \\
\text { patterns in } \\
\text { decision- } \\
\text { making, } \\
\text { applying } \\
\text { instructional } \\
\text { strategies and } \\
\text { understanding } \\
\text { of the impacts } \\
\text { of instructional } \\
\text { decisions. }\end{array}$ \\
\hline \multirow[t]{2}{*}{$\begin{array}{l}\text { GUIDING } \\
\text { PRINCIPE } \\
\mathbf{4} \\
\text { Supervision } \\
\text { of clinical } \\
\text { experience } \\
\text { directs } \\
\text { trainee } \\
\text { teachers } \\
\text { towards } \\
\text { best } \\
\text { practices in } \\
\text { school and } \\
\text { core } \\
\text { qualities of } \\
\text { a teacher. }\end{array}$} & $\begin{array}{l}\text { 1. Trainee } \\
\text { teachers are } \\
\text { aware of and } \\
\text { willing to } \\
\text { receive } \\
\text { training on } \\
\text { best practices } \\
\text { in school and } \\
\text { feedbacks on } \\
\text { core qualities } \\
\text { of a teacher } \\
\text { through } \\
\text { supervision of } \\
\text { clinical } \\
\text { experience. }\end{array}$ & $\begin{array}{l}\text { 1. Trainee } \\
\text { teachers } \\
\text { translate, } \\
\text { interpret and } \\
\text { extrapolate best } \\
\text { practices in } \\
\text { school and core } \\
\text { qualities through } \\
\text { supervision of } \\
\text { clinical } \\
\text { experience. }\end{array}$ & $\begin{array}{l}\text { 1. Trainee } \\
\text { teachers } \\
\text { understand } \\
\text { and develop } \\
\text { the knowledge } \\
\text { of best } \\
\text { practices in } \\
\text { school and } \\
\text { core qualities } \\
\text { of a teacher } \\
\text { through } \\
\text { constructive } \\
\text { feedbacks } \\
\text { from } \\
\text { supervisors } \\
\text { based on a } \\
\text { common, clear } \\
\text { vision of good } \\
\text { practices and } \\
\text { core qualities } \\
\text { grounded in } \\
\text { an } \\
\text { understanding } \\
\text { of teaching } \\
\text { and learning } \\
\text { through } \\
\text { supervision of } \\
\text { clinical } \\
\text { experience. }\end{array}$ \\
\hline & $\begin{array}{l}\text { 2. Trainee } \\
\text { teachers } \\
\text { acknowledge } \\
\text { best practices } \\
\text { in school and } \\
\text { core qualities }\end{array}$ & $\begin{array}{l}\text { 2. Trainee } \\
\text { teachers } \\
\text { demonstrate } \\
\text { characteristics } \\
\text { of best practices } \\
\text { in school context }\end{array}$ & $\begin{array}{l}\text { 2. Trainee } \\
\text { teachers } \\
\text { understand } \\
\text { the knowledge } \\
\text { of ways and } \\
\text { means of }\end{array}$ \\
\hline
\end{tabular}




\begin{tabular}{|c|c|c|c|}
\hline & $\begin{array}{l}\text { of a teacher } \\
\text { through } \\
\text { supervision of } \\
\text { clinical } \\
\text { experience. } \\
\text { 3. Trainee } \\
\text { teachers show } \\
\text { preference of } \\
\text { and } \\
\text { commitment } \\
\text { to best } \\
\text { practices in } \\
\text { the school } \\
\text { context and } \\
\text { core qualities } \\
\text { of a teacher } \\
\text { through } \\
\text { supervision of } \\
\text { clinical } \\
\text { experience. } \\
4 . \text { Trainee } \\
\text { teachers } \\
\text { conceptualize } \\
\text { the value of } \\
\text { best practice } \\
\text { in school and } \\
\text { core qualities } \\
\text { of a teacher } \\
\text { through } \\
\text { supervision of } \\
\text { clinical } \\
\text { experience. }\end{array}$ & $\begin{array}{l}\text { and display core } \\
\text { qualities of a } \\
\text { teacher through } \\
\text { supervision of } \\
\text { clinical } \\
\text { experience. } \\
\text { 3. Trainee } \\
\text { teachers } \\
\text { analyse } \\
\text { elements in best } \\
\text { practices and } \\
\text { core qualities of } \\
\text { a teacher } \\
\text { through } \\
\text { supervision of } \\
\text { clinical } \\
\text { experience. }\end{array}$ & $\begin{array}{l}\text { 3. Trainee } \\
\text { teachers } \\
\text { understand } \\
\text { the } \\
\text { professional } \\
\text { standards } \\
\text { referred to by } \\
\text { supervisors } \\
\text { that reflect } \\
\text { best practices } \\
\text { and core } \\
\text { qualities to be } \\
\text { translated and } \\
\text { demonstrated } \\
\text { in their } \\
\text { classroom } \\
\text { pedagogy and } \\
\text { practice } \\
\text { through } \\
\text { supervision of } \\
\text { clinical } \\
\text { experience. }\end{array}$ \\
\hline \multirow[t]{2}{*}{$\begin{array}{l}\text { GUIDING } \\
\text { PRINCIPLE } \\
\mathbf{5} \\
\text { Clinical } \\
\text { experience } \\
\text { exposes } \\
\text { trainee } \\
\text { teachers to } \\
\text { the } \\
\text { administrativ } \\
\text { e process } \\
\text { and school } \\
\text { activities. }\end{array}$} & $\begin{array}{l}\text { 1. Trainee } \\
\text { teachers are } \\
\text { aware of the } \\
\text { important } \\
\text { aspects of } \\
\text { administrative } \\
\text { process such } \\
\text { as motivation, } \\
\text { communicatio } \\
\text { n and } \\
\text { leadership. }\end{array}$ & $\begin{array}{l}\text { 1. Trainee } \\
\text { teachers } \\
\text { translate, } \\
\text { interpret and } \\
\text { extrapolate } \\
\text { knowledge, skill } \\
\text { and attitudes in } \\
\text { management } \\
\text { through the } \\
\text { clinical } \\
\text { experience and } \\
\text { the supervision. }\end{array}$ & $\begin{array}{l}\text { 1. Trainee } \\
\text { teachers } \\
\text { understand } \\
\text { the functions } \\
\text { of } \\
\text { administrative } \\
\text { in order to } \\
\text { plan, organize, } \\
\text { command, } \\
\text { coordinate and } \\
\text { control the } \\
\text { process or } \\
\text { activity of } \\
\text { running a } \\
\text { school. }\end{array}$ \\
\hline & $\begin{array}{l}\text { 2. Trainee } \\
\text { teachers are } \\
\text { willing to face } \\
\text { the problem } \\
\text { dealing with } \\
\text { the } \\
\text { administrative } \\
\text { process and } \\
\text { the school } \\
\text { activity. }\end{array}$ & $\begin{array}{l}\text { 2. Trainee } \\
\text { teacher is able } \\
\text { to manage } \\
\text { school efficiently } \\
\text { and effectively } \\
\text { through the } \\
\text { understanding of } \\
\text { the function of } \\
\text { school } \\
\text { administrative } \\
\text { process and } \\
\text { activity of } \\
\text { running school. }\end{array}$ & $\begin{array}{l}\text { 2. Trainee } \\
\text { teacher realise } \\
\text { the necessity } \\
\text { of physical } \\
\text { qualities, } \\
\text { mental } \\
\text { qualities, } \\
\text { moral } \\
\text { qualities, } \\
\text { general } \\
\text { education and } \\
\text { work } \\
\text { experience in } \\
\text { the school }\end{array}$ \\
\hline
\end{tabular}

\begin{tabular}{|c|c|c|}
\hline $\begin{array}{l}\text { 3. Trainee } \\
\text { teachers are } \\
\text { aware of and } \\
\text { willing to } \\
\text { receive } \\
\text { training on } \\
\text { administrative } \\
\text { process or } \\
\text { activity of } \\
\text { running a } \\
\text { school during } \\
\text { teaching } \\
\text { practice. }\end{array}$ & $\begin{array}{l}\text { 3. Trainee } \\
\text { teachers are } \\
\text { able to ensure } \\
\text { that the activities } \\
\text { are carried out } \\
\text { in line with } \\
\text { agreed } \\
\text { standards and } \\
\text { taking steps to } \\
\text { correct problems }\end{array}$ & $\begin{array}{l}\text { administrative } \\
\text { process } \\
\text { through the } \\
\text { supervision of } \\
\text { clinical } \\
\text { experience. } \\
\text { 3. Trainee } \\
\text { teachers } \\
\text { understand } \\
\text { that school } \\
\text { administration } \\
\text { and } \\
\text { supervision } \\
\text { should be } \\
\text { cooperative to } \\
\text { develop } \\
\text { results from } \\
\text { the combined } \\
\text { efforts of all } \\
\text { administrators, } \\
\text { supervisors, } \\
\text { teachers, } \\
\text { parents and } \\
\text { pupils. } \\
4 . \text { Trainee } \\
\text { teachers } \\
\text { understand } \\
\text { how to apply } \\
\text { knowledge, } \\
\text { skills and } \\
\text { attitudes in } \\
\text { educational } \\
\text { management } \\
\text { to enable } \\
\text { more effective } \\
\text { and efficient } \\
\text { planning of } \\
\text { resources for } \\
\text { use in your } \\
\text { school, } \\
\text { organising and } \\
\text { co-ordinating } \\
\text { of school } \\
\text { programmes, } \\
\text { projects and } \\
\text { activities, and } \\
\text { managing and } \\
\text { evaluating of } \\
\text { the teaching } \\
\text { and learning } \\
\text { processes in } \\
\text { school. }\end{array}$ \\
\hline
\end{tabular}

\section{CONCLUSION}

This study embarks on the objective to produce guiding principles for teacher clinical experience and induction for preparing quality teacher for the future. Based on the analysis of data, five main guiding principles in three perspectivesvalues, skills, and knowledge were proposed. These guiding principles can be referred by the teacher education institution in developing their curriculum framework to produce quality teacher for the future. The guiding principles have to be translated into a teacher education model and should be piloted to validate the suggested principles. For the next level, an impact study should be carried out to gauge the effectiveness of the Clinical Experience and Induction Model for preparing quality teachers before it can be refined and finalized. 


\section{REFERENCES}

[1] A. Colin, J. S.Brown, \& S. E. Newman, Cognitve apprenticeship: teaching the crafts of reading, writing, and mathematics. In L. B. Resnick (Ed), Knowing, learning and insrtruction: Essay in honor of Robert Glaser, Hillsdale: NJ: Erlbaum, 1989, pp. 453-494.

[2] A. Tan, Does Scaffolding Blogging Promote Preservice Teacher Reflection? Examining The Relationship Between Learning Tool and Scaffolding in a Blended Learning Enviroment. (Doctoral Dissertation). Indiana, United State of America: Indiana University, 2006.

[3] A. Villareal, Ten Principles that Guide the Development on an Effective Education Plan for English Language Learners at Secondary Level Part II. Texas: Intercultural Development Research Association, 2009.

[4] E. Cohen-Sayag, \& D. Fischl, "Reflective writing pre-service teachers' teaching: What does it promote?", Australian Journal of Teacher Education, 37(10), 2012, pp. 19-36. https://doi.org/10.14221/ajte.2012v37n10.1

[5] Fauziah Abd Majid. "The use of reflective journals in outcome-based education during the teaching practicum," Malaysian Journal of ELT Research, 4, 2008, pp. 32-42.

[6] G. Ewart, \& S. Straw, "A Seven-Month Practicum: Collaborating Teachers' Response," Canadian Journal of Education, 28(1\&2), 2005, pp. 185-202.

[7] K. Barry, \& L. King, Beginning teaching and beyond (Third ed.). Tunggerah: NSW: Social Science Press, 2002.

[8] L. Atputsamy, "Cooperating teachers as school based teacher educators: Student teachers' expectations," Australian Journal of Teacher Education 30 (2), 2005. Retrieved February 4, 2008, from http://aje.education.ecu.au/issues/PDF/Thirtytwo/aptuphasamy.pdf https://doi.org/10.14221/ajte.2005v30n2.1

[9] L. Darling-Harmmond, Powerful teacher education: Lesson from exemplary programs. San Francisco: Joey-Bass, 2006.

[10] L. Grudnoff, "Rethinking the practicum: limitation and possibilities," Asia-Pasific Journal of Teacher Education, 2011, pp. 223-234

[11] Melor Md. Yunus, Harwati Hashim, Noriah Mohd Ishak, \& Zamri Mahamod, "Understanding TESL pre-service teachers' teaching experiences and challenges via post-practicum reflection forms," Procedia Social and Behavorial Sciences, 9, 2010, pp. 722-728. Retrieved March 8, 2011, from http://doi:10.1016/j.sbspro.2010.12.224

[12] R. Beach, \& D. Pearson, "Changes in preservice teachers' perceptions of conflicts and tension," Teaching and Teacher Education, 14(3), 1998, p. 337-351. https://doi.org/10.1016/S0742-051X(97)00041-3

[13] R. Blunden, "Rethinking the place of practicum in teacher education," Australian Journal of Teacher Education, 1(25), 2000, pp. 1-16. https://doi.org/10.14221/ajte.2000v25n1.1

[14] R. Cameron, \& S. Wilson, "The practicum: student teacher perception of teacher supervision styles," South Pacific Journal of Teacher Education, 21(2), 1993, pp. 155-167. https://doi.org/10.1080/0311213930210208

[15] S. C. Goh, \& B. Matthews, "Listening to the concerns of pre-service teachers in Malaysia during teaching practice," Australian Journal of Teacher Education, 36(3), 2011, pp. 92-103. https://doi.org/10.14221/ajte.2011v36n3.2

[16] S. Etscheidt, C. M. Curran, \& C. M. Sawyer, "Promoting reflection in teacher preparation programs: A multilevel model," Teacher Education and Special Education, 35, 2011, pp. 7-26. Retrieved January 4, 2012, from http://doi:10.1177/0888406411420887

[17] S. Veenman, "Perceived problem of beginning teachers," Review of Educational Research, 19(3), 1984, pp. 143-178. https://doi.org/10.3102/00346543054002143

[18] Wasim Qazi, Khalid Jamil Rawat, \& M. Thomas, "The role of practicum in enhancing student teachers' teaching skills," American Journal of Scientific Research, 44, 2012, pp. 44-57. 